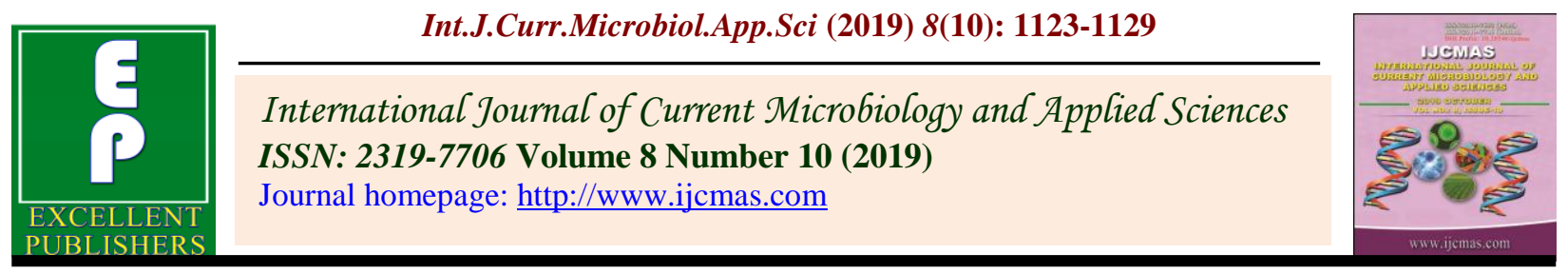

Original Research Article https://doi.org/10.20546/ijcmas.2019.810.131

\title{
Constraints in Involvement of Tribal Youth in Agricultural Enterprises in Odisha, India
}

\author{
Debashis Dash*, Amardeep, V.L.V. Kameswari and Neelam Bhardwaj \\ Department of Agricultural Communication, Gobind Ballabh Pant University of Agriculture \\ and Technology, Pantnagar, Uttarakhand, India \\ *Corresponding author
}

\begin{tabular}{|c|}
\hline Keywords \\
\hline $\begin{array}{l}\text { Tribal agriculture, } \\
\text { Tribal youth, } \\
\text { Agricultural } \\
\text { enterprises and } \\
\text { Constraints }\end{array}$ \\
\hline Article Info \\
\hline $\begin{array}{l}\text { Accepted: } \\
\text { 10 September } 2019 \\
\text { Available Online: } \\
10 \text { October } 2019\end{array}$ \\
\hline
\end{tabular}

\section{Keywords}

Tribal agriculture,

Tribal youth

Agricultural

enterprises and

Constraints

\section{Article Info}

Accepted:

Available Online:

\section{Introduction}

Indian agriculture has been experiencing transition from green revolution to evergreen revolution, farm employment to selfemployment and agricultural development to agri-business development over the years. The development approaches in agriculture have also witnessed paradigm shift viz. productivity to profitability, where the focus is on increasing the production efficiency while
Tribal agriculture in India demands youth skilled in scientific farming. Tribal youth are active stake holders in agripreneurship design and can transform tribal communities on a sustainable basis. Lack of desired skills among tribal youth makes them vulnerable when compared to their rural and urban counterparts. Making them employable in various agricultural enterprises is a major challenge in front of the government as tribal youth face a plethora of problems which hinder their active participation. The present study attempted to analyse various personal, social, technological, economic and other miscellaneous constraints faced by tribal youth in undertaking various agricultural enterprises. A descriptive and analytical research design was used to meet the objectives of the study. The study was carried out in Koraput district of Odisha which was selected purposively. Three blocks were selected randomly and 12 villages were selected purposively. The study was carried out on a sample of 246 tribal youth who were selected through proportional allocation from the selected villages and were interviewed using a pre-tested structured schedule. Lack of role model, lack of faith from old family members, lack of information about improved agricultural technologies, lack of profits and lack of extension activities were the major constraints faced by the tribal youth in various agricultural enterprises. 
Tribal people are considered as the original habitants of India and play a significant role in developing cultural habitat of India. Tribal development is essential for a developing country like India because it is home to more than104 million tribal people and they contribute 8.4 per cent of India's total population (2011 Census). Tribal youth constitute a numerically dominant, potentially resourceful and also adventurous segment of the population who lack higher education, awareness and advanced communication systems and technology (Dash, Amardeep and Mahra, 2018). Unlike urban youth who are mostly educated and organized in many forms and have access to facilities and institutions meant for youth services, tribal youth are mostly illiterate, burdened by the needs of their families, lack opportunities to engage in constructive work and guidance for participation in development activities (Rana and Verma, 2017). Freak climatic conditions, lack of ownership rights over lands, ignorance and illiteracy, chronic indebtness have made the life of tribals very difficult (Burman, 1993). In order to cope up with the changes in agriculture, the tribal youth need a motivational shift. The future generation of youth is important for food production and food security at domestic, regional and global level (Proctor and Lucchese, 2012).Several constraints viz. individual, social, economic and technological constraints hinder tribal youth from undertaking various agricultural enterprises for sustaining their livelihood. Vocational training of tribal youth in agriculture related areas is considered as one of the potential solutions for mitigating the problems of growing unemployment. New opportunities are available in the form of cattle rearing, poultry, fishing, bee-keeping, organic farming, floriculture, sericulture etc. The state of Odisha has second highest tribal concentration among the states of India and ranks next to Madhya Pradesh. Around 62 tribes comprise of 24 per cent of total population of the state. The present study was conducted in Odisha state for analyzing the constraints faced by tribal youth in choosing agricultural enterprises.

\section{Materials and Methods}

Odisha state is predominantly an agrarian state and it is home to the largest number of tribes (62) out of the 437 tribes present in the country. Koraput district was selected purposively because it is the only district where almost all the tribes of Odisha are present. Out of fourteen administrative blocks, Laxmipur block, Narayanpatna block and Bandhugaon block were chosen randomly by using simple random sampling without replacement. Three villages from each block i.e. 12 villages were selected purposively considering size of village population $(>500)$, villages comprising of more than 50 per cent of tribal youth and tribal youth undertaking some form of agricultural work for livelihood purpose. Using Cochran's formula, the estimated sample size was calculated assuming the variability to 20 per cent (i.e. $p$ $=0.2$ ) and taking 95 per cent confidence level with \pm 5 per cent precision.

$$
n_{\mathrm{o}}=\frac{Z^{2} p q}{\boldsymbol{e}^{2}}
$$

Where, $\mathrm{n}_{0=}$ sample size

$\mathrm{Z}=$ selected critical value of desired confidence level

$\mathrm{p}=$ estimated proportion of an attribute that is present in the population

$q=1-p$, estimated proportion of an attribute that is not present in the population $\mathrm{e}=$ desired level of precision

Therefore, 246 tribal youth were selected through proportional allocation for attainment of pre-determined objectives. The data were collected and analyzed by using appropriate 
statistical tools like frequency, percentage, mean, S.D., correlation coefficient, multiple regression analysis etc. The constraint analysis was carried out using Garrett's ranking method. As per this method, respondents have been asked to assign the rank for all factors and the outcomes of such ranking have been converted into score value with the help of the following formula:

\section{Percent position $=100\left(R_{i j}-0.5\right) / N_{j}$}

Where,

$\mathrm{R}_{\mathrm{ij}}=$ Rank given for the $\mathrm{i}^{\text {th }}$ variable by $\mathrm{j}^{\text {th }}$ respondents

$\mathrm{N}_{\mathrm{j}}=$ Number of variable ranked by $\mathrm{j}^{\text {th }}$ respondents

With the help of Garrett's Table, the percent position estimated is converted into Garrett scores. Later, for each factor, the scores of each individual were added, total value of scores and mean values of score were calculated. Then, the constraints were ranked on the basis of highest mean value.

\section{Results and Discussion}

The constraints reported by the respondents were grouped into five categories viz. personal, social, technological, economic and other miscellaneous constraints.

Perceived constraints to tribal youths' involvement in agricultural enterprises

\section{Personal constraints}

Personal constraints are associated with certain associative actions of tribal youth such as friendship or kinship etc. It is clear from Table 1 that, personal constraints viz. lack of role model, lack of patience, lack of excitement in contributing towards agricultural activities, lack of high occupational aspiration, lack of information about establishment of several agricultural enterprises, lack of parental support for agriculture, no incentives to young farmers, lack of education among tribal youth and lack of leadership and confidence affected their choice in undertaking agricultural enterprises respectively.

\section{Social constraints}

Social constraints are associated with the constraints dealing with the community environment, societal stratification and distribution of power. These constraints are the patterns of behavior or attributes of tribal youth that influence participation in agricultural enterprises. It is clear from Table 2 that, social constraints viz. lack of faith from old family members, early marriage, engagement of tribal youth in many unproductive activities, lack of time due to excessive involvement in other societal activities and lack of participation in community activities affected their choice in undertaking agricultural enterprises respectively.

\section{Technological constraints}

Technological constraints are related with technical facilities of tribal youth. Sometimes technologies are developed for knowledge purpose only without considering actual problems of the tribal youth.

Table 3 depicts technological constraints viz. lack of diffusion of improved agriculture technology, poor transportation facility, lack of effective inputs in time, high cost of new agricultural technologies, lack of practical oriented training facility for skill development and poor marketing facility affected their choice in undertaking agricultural enterprises respectively. 


\section{Economic constraints}

Economic constraints are the external constraints which are beyond the control of tribal youth. It is associated with fluctuations in price of agricultural inputs to varying market conditions of agricultural products. It is evident from Table 4 that, economic constraints viz. lack of profits, financial instability in family, high cost of agricultural implements, lack of credit facility through concerned efforts on time, non-utilization of leisure time activity and no future in agriculture as operational land holding is very low affected their choice in undertaking agricultural enterprises respectively.

Table.1 Personal constraints militating tribal youths' involvement in agricultural enterprises

\begin{tabular}{|c|c|c|c|c|c|}
\hline S.No & Personal Constraints & $\begin{array}{l}\text { Percentage } \\
\text { Position }\end{array}$ & $\begin{array}{l}\text { Garrett's } \\
\text { table value }\end{array}$ & $\begin{array}{l}\text { Garrett's } \\
\text { Avg. Score }\end{array}$ & Rank \\
\hline 1. & $\begin{array}{l}\text { Lack of high occupational } \\
\text { aspiration }\end{array}$ & 5.55 & 81 & 50.73 & $4^{\text {th }}$ \\
\hline 2. & $\begin{array}{l}\text { Lack of information } \\
\text { establishment of } \\
\text { agricultural enterprises }\end{array}$ & 16.67 & 69 & 50.54 & $5^{\text {th }}$ \\
\hline 3. & Lack of education & 27.78 & 62 & 47.62 & $8^{\text {th }}$ \\
\hline 4. & $\begin{array}{l}\text { Lack of excitement in } \\
\text { contributing towards agricultural } \\
\text { activities }\end{array}$ & 38.39 & 56 & 51.50 & $3^{\text {rd }}$ \\
\hline 5. & $\begin{array}{l}\text { Lack of Parental Support for } \\
\text { agriculture }\end{array}$ & 50 & 50 & 49.70 & $6^{\text {th }}$ \\
\hline 6. & Lack of role model & 61.11 & 44 & 52.57 & $1^{\mathrm{st}}$ \\
\hline 7. & $\begin{array}{l}\text { Lack of leadership and } \\
\text { confidence }\end{array}$ & 72.22 & 38 & 47.40 & $9^{\text {th }}$ \\
\hline 8. & No incentives to young farmers & 83.33 & 31 & 48.47 & $7^{\text {th }}$ \\
\hline 9. & Lack of patience & 94.44 & 19 & 51.75 & $2^{\text {nd }}$ \\
\hline
\end{tabular}

Table.2 Social constraints militating tribal youths' involvement in agricultural enterprises

\begin{tabular}{|c|c|c|c|c|c|}
\hline S.No & Social Constraints & $\begin{array}{l}\text { Percentage } \\
\text { Position }\end{array}$ & $\begin{array}{l}\text { Garrett's } \\
\text { table value }\end{array}$ & $\begin{array}{c}\text { Garrett's } \\
\text { Avg. Score }\end{array}$ & Rank \\
\hline 1. & $\begin{array}{l}\text { Engagement of tribal youth in many } \\
\text { unproductive activities }\end{array}$ & 10 & 75 & 48.98 & $3^{\text {rd }}$ \\
\hline 2. & $\begin{array}{l}\text { Lack of participation in community } \\
\text { activities }\end{array}$ & 30 & 60 & 46.89 & $5^{\text {th }}$ \\
\hline 3. & $\begin{array}{l}\text { Lack of faith from old family } \\
\text { members }\end{array}$ & 50 & 50 & 53.71 & $1^{\text {st }}$ \\
\hline 4. & Early marriage & 70 & 40 & 51.37 & $2^{\text {nd }}$ \\
\hline 5. & $\begin{array}{l}\text { Lack of time due to excessive } \\
\text { involvement in other societal } \\
\text { activities }\end{array}$ & 90 & 24 & 48.05 & $4^{\text {th }}$ \\
\hline
\end{tabular}


Table.3 Technological constraints militating tribal youths' involvement in agricultural enterprises

\begin{tabular}{|c|l|c|c|c|c|}
\hline S.No & Technological Constraints & $\begin{array}{c}\text { Percentage } \\
\text { Position }\end{array}$ & $\begin{array}{c}\text { Garrett's } \\
\text { table value }\end{array}$ & $\begin{array}{c}\text { Garrett's } \\
\text { Avg. Score }\end{array}$ & Rank \\
\hline $\mathbf{1 .}$ & $\begin{array}{l}\text { Lack of information about improved } \\
\text { agriculture technology }\end{array}$ & 8.33 & 77 & 53.52 & $1^{\text {st }}$ \\
\hline $\mathbf{2 .}$ & $\begin{array}{l}\text { Lack of practical oriented training facility } \\
\text { for skill development }\end{array}$ & 25 & 63 & 48.24 & $5^{\text {th }}$ \\
\hline $\mathbf{3 .}$ & Lack of effective inputs in time & 41.67 & 54 & 50.32 & $3^{\text {rd }}$ \\
\hline $\mathbf{4 .}$ & High cost of new agricultural technologies & 58.33 & 46 & 50.04 & $4^{\text {th }}$ \\
\hline $\mathbf{5 .}$ & Poor transportation facility & 75 & 37 & 52.72 & $2^{\text {nd }}$ \\
\hline $\mathbf{6 .}$ & Poor marketing facility & 91.67 & 23 & 45.16 & $6^{\text {th }}$ \\
\hline
\end{tabular}

Table.4 Economic constraints militating tribal youths' involvement in agricultural enterprises

\begin{tabular}{|c|c|c|c|c|c|}
\hline S.No & Economic Constraints & $\begin{array}{l}\text { Percentage } \\
\text { Position }\end{array}$ & $\begin{array}{l}\text { Garrett's } \\
\text { table value }\end{array}$ & $\begin{array}{l}\text { Garrett's } \\
\text { Avg. Score }\end{array}$ & Rank \\
\hline 1. & $\begin{array}{l}\text { Lack of credit facility through } \\
\text { concerned efforts on time }\end{array}$ & 8.33 & 77 & 48.85 & $4^{\text {th }}$ \\
\hline 2. & Lack of profits & 25 & 63 & 52.65 & $1^{\mathrm{st}}$ \\
\hline 3. & $\begin{array}{l}\text { No future in agriculture as } \\
\text { operational land holding is very low }\end{array}$ & 41.67 & 54 & 48.26 & $6^{\text {th }}$ \\
\hline 4. & Financial instability in family & 58.33 & 46 & 52.61 & $2^{\text {nd }}$ \\
\hline 5. & High cost of agricultural implements & 75 & 37 & 49.17 & $3^{\text {rd }}$ \\
\hline 6. & $\begin{array}{l}\text { Non utilization of leisure time } \\
\text { activity }\end{array}$ & 91.67 & 23 & 48.46 & $5^{\text {th }}$ \\
\hline
\end{tabular}

Table.5 Miscellaneous constraints militating tribal youths' involvement in agricultural enterprises

\begin{tabular}{|c|c|c|c|c|c|}
\hline S. No & Miscellaneous Constraints & $\begin{array}{l}\text { Percentage } \\
\text { Position }\end{array}$ & $\begin{array}{l}\text { Garrett's } \\
\text { table value }\end{array}$ & $\begin{array}{l}\text { Garrett's } \\
\text { Avg. Score }\end{array}$ & Rank \\
\hline 1. & $\begin{array}{l}\text { Lack of awareness about various agricultural } \\
\text { development programmes }\end{array}$ & 8.33 & 77 & 51.01 & $3^{\text {rd }}$ \\
\hline 2. & $\begin{array}{l}\text { Delay in implementation of government } \\
\text { schemes }\end{array}$ & 25 & 63 & 48.52 & $5^{\text {th }}$ \\
\hline 3. & $\begin{array}{l}\text { Lack of extension activities i.e. Kisan Mela, } \\
\text { Training and Demonstration, Field Visits } \\
\text { etc. in remote areas }\end{array}$ & 41.67 & 54 & 52.58 & $1^{\text {st }}$ \\
\hline 4. & Exploitation from middlemen & 58.33 & 46 & 49.89 & $4^{\text {th }}$ \\
\hline 5. & $\begin{array}{l}\text { Preferring urban enterprises over rural } \\
\text { enterprises }\end{array}$ & 75 & 37 & 51.15 & $2^{\text {nd }}$ \\
\hline 6. & $\begin{array}{l}\text { Out-Migration towards cities due to lack of } \\
\text { livelihood opportunities in villages }\end{array}$ & 91.67 & 23 & 46.85 & $6^{\text {th }}$ \\
\hline
\end{tabular}


Table.6 Suggestions offered by tribal youth to overcome their constraints (Multiple Responses)

\begin{tabular}{|r|l|c|c|}
\hline S. No & Suggestions & Number & Percentage \\
\hline 1. & $\begin{array}{l}\text { Publish the list of beneficiary farmers as role models in the } \\
\text { village }\end{array}$ & 160 & 65.04 \\
\hline 2. & Timely availability of agricultural inputs and information & 146 & 59.35 \\
\hline 3. & $\begin{array}{l}\text { Training should be given on improved agricultural practices in } \\
\text { several agricultural enterprises }\end{array}$ & 171 & 69.51 \\
\hline 4. & $\begin{array}{l}\text { Regular monitoring and feedback by implementing agencies } \\
\text { 5. }\end{array}$ & $\begin{array}{l}\text { Extension activities i.e. kisan mela, demonstration, exhibition, } \\
\text { training, visits etc. should be conducted at block and village level } \\
\text { at proper time }\end{array}$ & 133 \\
\hline 6. & $\begin{array}{l}\text { Creating awareness and motivating tribal youth to participate in } \\
\text { various agricultural development schemes providing } \\
\text { employment }\end{array}$ & 129 & 54.07 \\
\hline
\end{tabular}

\section{Miscellaneous constraints}

It is clear from Table 5 that, miscellaneous constraints viz. lack of extension activities i.e. kisan mela, training and demonstration, field visits etc. in remote areas, preferring urban enterprises over rural enterprises, lack of awareness about various agricultural development programmes, high cost of agricultural implements, exploitation from middlemen, delay in implementation of government schemes and out-migration towards cities due to lack of livelihood opportunities in villages affected their choice in undertaking agricultural enterprises respectively.

It was observed that lack of role model, lack of faith of old family members, lack of information about improved agricultural technologies, lack of profits and lack of extension activities were the most significant constraints. The findings are in line with Dhanush and Murugan (2018) and Mankar et al., (2000). Most of the tribal youth expressed that role models in agriculture were very less in the tribal areas. They also felt that there were problems in choosing appropriate vocations due to lack of proper guidance.
Tribal youth felt that preference of any agricultural vocation as livelihood other than their ancestors' profession would lose their values and traditions as well as faith from old family members. As tribal youth reside in difficult terrains, diffusion of new agricultural technologies was very slow in comparison to their urban and rural counterparts. Another economic constraint reported was lack of profits because of lack of market for their produce. This paved the way for switching to other non-agricultural vocations. Lack of effective extension activities in the form of various periodic agricultural trainings limited their choice of choosing different agricultural enterprises.

As regards to suggestions given by tribal youth to overcome the constraints and for improving the participation of tribal youth in various agricultural enterprises, the findings are presented in Table 6. The findings revealed that majority of the respondents felt that regular and continuous training should be given on improved agricultural practices in several agricultural enterprises (69.51\%) followed by publication of the list of beneficiary farmers as role models in the village $(65.04 \%)$, regular monitoring and 
feedback by implementing agencies $(60.98 \%)$, timely availability of agricultural inputs and information (59.35\%), extension activities i.e. kisan mela, demonstration, exhibition, training, visits etc. should be conducted at block and village level at proper time $(54.07 \%)$ and creating awareness and motivating tribal youth to participate in various agricultural development schemes providing employment $(52.44 \%)$ are required for overcoming the constraints regarding their involvement in agricultural enterprises.

In conclusion, the study has shown that tribal youth have a plethora of problems which need to be dealt with by the government. The involvement of tribal youth in agriculture can be facilitated through livelihood generation programmes, entrusting more and more integrated farming system to combine agriculture with other enterprises like horticulture, apiculture, fisheries, animal resources, sericulture, etc. Such a move would also require sufficient funds for starting new agricultural enterprises in the tribal villages. In order to appeal and motivate tribal youth, regular trainings must be conducted in remote villages after assessing their training needs. In this context, it is necessary that government should plan proper programmes for tribal youth on the basis of the constraints faced by them.

\section{References}

Mankar, D.M., Marawar, S.S., Ratnalikar, D.V. and Raut, R. S. 2009. Sustainable rural livelihood security in disadvantage district of Maharashtra - Social aspect. Agrosco Report; Dr. Panjabrao Deshmukh Krishi Vidyapeeth, Akola (M.S.) India.

Dhanush, S. and Murugan, P.P. 2019. Constraints faced by the Tribal Youth in Vocational Preference. Journal of Extension Education, 30(3): 6146-6149

Dash, D., Amardeep, and Mahra, G. S. 2018. Generating livelihood for tribal youth through agripreneurship development: Prospects, retrospect, constraints and strategies. Journal of Pharmacognosy and Phytochemistry, 7(5): 3412-3416.

Rana, S. and Verma, R. K. 2017. Tribal Youth Related Issues in India and Positive Youth Development Approach. Journal of Advanced Research in Humanities and Social Science. 4(1): 21-29.

Roy Burman, B.K. 1993. Tribal development in world system perspective, Social change, 23 (2-3): 27-32.

Proctor, F. J. and Lucchese, V. 2012. Small Scale Farming and Youths in an era of Rapid Rural Change. IIED/HIVOS: London, [http://un.org/youths] accessed on 15th April, 2019.

\section{How to cite this article:}

Debashis Dash, Amardeep, V.L.V. Kameswari and Neelam Bhardwaj. 2019. Constraints in Involvement of Tribal Youth in Agricultural Enterprises in Odisha, India. Int.J.Curr.Microbiol.App.Sci. 8(10): 1123-1129. doi: https://doi.org/10.20546/ijcmas.2019.810.131 